Efektifitas penggunaan ekstrak buah mahkota dewa (Phaleria macrocarpa) untuk pencegahan serangan bakteri Aeromonas hydrophilla pada ikan

\title{
kerapu macan
}

[The effectiveness of the use of the extract of the fruit of the Dewa's Crown (Phaleria macrocarpa) to prevent the attack of the Aeromonas hydrophilla bacteria on tiger grouper]

\section{Nilawati $^{1^{*}}$, Rindhira Humairani ${ }^{1}$}

\section{${ }^{1}$ Program Studi Akuakultur, Fakultas Pertanian Universitas Almuslim. Jln. Almuslim Matangglumpangdua, Bireuen-Aceh}

ABSTRACT | The research was aimed to determine the effectiveness of brown marbled grouper treatment was using crown of god extracts. Research with experimental methods using a completely randomized design (CRD) with 3 treatments and 3 replications. The result of the research showed that treatment $\mathrm{B}$ with $2 \mathrm{ml}$ of crown of god extracts/ $8 \mathrm{ml}$ mineral water through soaking has lowest prevalence level of bacterial attacking Aeromonas hydrophilla, it was $80 \%$, while highest prevalence level of bacterial attacking was found in treatment C (control) achieved 100\%.

Key words $\mid$ Crown of god extract, brown-marbled grouper, attacking prevalence, Aeromonas hydrophilla

ABSTRAK| Penelitian ini bertujuan untuk mengetahui efektifitas pengobatan ikan kerapu dengan menggunakan ekstrak buah mahkota dewa. Penelitian dengan metode eksperimental menggunakan Rancangan Acak Lengkap (RAL) dengan 3 perlakuan 3 ulangan. Hasil penelitian menunjukkan perlakuan B dengan pemberian $2 \mathrm{ml}$ ekstrak buah mahkota dewa/ $8 \mathrm{ml}$ aquades secara perendaman memiliki tingkat prevalensi serangan bakteri Aeromonas hydrophilla paling rendah yaitu $80 \%$, sedangkan tingkat prevalensi serangan tertinggi ditunjukan pada perlakuan C (kontrol) yang mencapai $100 \%$.

Kata kunci | Ekstak buah mahkota dewa, ikan kerapu macan, prevalensi serangan, Aeromonas hydrophilla

Received | 27 September 2020, Accepted | 26 Oktober 2020, Published | 16 November 2020.

*Koresponden|Khairatun Nisak, Program Studi Akuakultur, Fakultas Pertanian Universitas Almuslim. Jln. Almuslim Matangglumpangdua, Bireuen-Aceh. Email: nilawat@gmail.com

Kutipan | Nilawati, N., \& Humairani, R. (2020). Efektifitas penggunaan ekstrak buah mahkota dewa (Phaleria macrocarpa) untuk pencegahan serangan bakteri Aeromonas hydrophilla pada ikan kerapu macan. Arwana: Jurnal Ilmiah Program Studi Perairan, 2(2), 130-135.

ISSN (Media Cetak) | 2657-0254

\section{PENDAHULUAN}

Kabupataen Bireuen merupakan wilayah pengembangan minapolitan di Propinsi Aceh. Kabupaten Bireuen mempunyai garis pantai dan area lahan tambak yang luas, sehingga memilki potensi yang besar dalam pengembangan perikanan. Ikan kerapu macan (Epinephelus fuscoguttatus) merupakan ikan yang banyak dibudidayakan di wilayah Kabupaten Bireuen dalam keramba jaring apung (KJA) dan tambak. Ikan ini merupakan ikan yang memilki harga jual yang tinggi dan menjadi salah satu komoditas ekspor yang memiliki potensi pengembangan yang cukup tinggi.

Pengembangan budidaya perikanan budidaya kerapu saat ini mempunyai beberapa kendala, diantaranya serangan penyakit pada ikan budidaya. Penyakit merupakan salah satu faktor yang menyebabkan kerugian yang sangat besar pada kegiatan budidaya kerapu, karena dapat menghambat pertumbuhan ikan kerapu bahkan menyababkan kematian masal. Jenis penyakit pada ikan kerapu dapat disebabkan oleh bakteri dan virus, ditandai dengan timbulnya bintik putih, borok pada bagian kulit dan sirip, pembusukan sirip dan mulut merah.

Penyakit yang lebih dominan menyerang ikan kerapu adalah penyakit bakterial sampai saat ini, seperti vibrio sp. Pengendalian penyakit pada ikan kerapu yang dilakukan oleh masyarakat Kabupaten Bireuen masih 
menggunakan obat kimia yang dijual dipasaran. Penggunaan bahan kimia dalam penanganan penyakit pada ikan kerapu dapat berbahaya bagi manusia dalam jangka panjang.

Selain itu penggunaan bahan kimia dalam pengendalian penyakit pada ikan kerapu menyebabkan kerusakan lingkungan (residu bahan kimia) dan kekebalan (resistensi) pada patogen penyebab penyakit pada ikan kerapu. Oleh karena itu, penggunaan bahan kimia harus dihindari dengan mencari bahan alternatif obat lainnya yang bersifat alami dalam mengobati penyakit pada ikan kerapu macan.

Penggunaan berbagai jenis tanaman sebagai obat alternatif sangat bermanfaat dalam kegiatan budidaya perikanan khususnya budidaya ikan kerapu, disebabkan murah, mudah didapat, tidak berbahaya bagi konsumen dan ramah lingkungan. Tanaman mahkota dewa (Phaleria macrocarpa) merupakan salah satu tanaman yang banyak terdapat di wilayah tropis dan telah banyak digunakan sebagai bahan baku obat oleh masyarakat. Buah mahkota dewa merupakan bagian dari tanaman mahkota dewa yang banyak digunakan untuk bahan obat karena dalam kulit buah mahkota dewa terdapat kandungan senyawa kimia yang bersifat antibakteri dan antijamur seperti flavonoid. Selain itu buah mahkota dewa juga mengandung beberapa senyawa kimia lainnya, seperti alkaloid, saponin, dan polifenol (Widyastuti et al., 2006).

Banyaknya penelitian mengenai pengobatan herbal pada bidang perikanan membuat peneliti ingin meneliti efektifitas buah mahkota dewa sebagai alternatif obat dalam menangani masalah serangan penyakit bakteri pada ikan kerapu macan. Dalam penelitian ini diharapkan penggunaan buah mahkota dewa dalam menangani kasus serangan penyakit bakteri pada ikan kerapu macan efektif.

Berdasarkan latar belakang di atas dapat dirumuskan masalah serangan penyakit bakteri pada ikan kerapu macan dapat menyebabkan kerugian pada kegiatan budidaya ikan kerapu macan dan penggunaan bahan herbal dari buah mahkota dewa diharapkan dapat mengatasi masalah serangan penyakit bakteri pada ikan kerapu macan. Tujuan dari penelitian ini adalah untuk mengetahui persentasi efektifitas pengobatan dengan buah mahkota dewa terhadap kelangsungan hidup ikan kerapu.

\section{BAHAN DAN METODE}

Penelitian ini telah dilaksanakan di Laboratorium Budidaya Perairan Universitas Almuslim dan Laboratorium PT. Cetra Proteina Prima Kabupaten Bireuen.

\section{Metode Penelitian}

Penelitian ini menggunakan metode eksperimen, yaitu dengan memberikan ekstrak buah mahkota dewa pada ikan kerapu yang akan di uji tantang dengan menggunakan bakteri Aeromonas hydrophiila $10^{5} \mathrm{CFU} / \mathrm{ml}$ dengan dosis yang berbeda untuk melihat efektifitas daya hambatnya pada ikan kerapu.

\section{Rancangan Percobaan}

Adapun rancangan percobaan yang akan digunakan dalam penelitian ini adalah Rancangan Acak Lengkap (RAL) dengan 3 perlakuan dan 3 kali ulangan. Adapun dosis ekstrak buah mahkota dewa yang akan digunakan dalam penelitian ini sesuai dengan (Wahjuningrum et al., 2007), adalah : A: $1 \mathrm{ml}$ ekstrak mahkota dewa/ $9 \mathrm{ml}$ aquades, B: $2 \mathrm{ml}$ ekstrak mahkota dewa / $8 \mathrm{ml}$ aquades C: $0 \mathrm{ml}$ (kontrol)

\section{Persiapan Wadah}

Wadah yang digunakan dalam penelitian ini adalah aquarium dengan ukuran $15 \times 20 \times 30 \mathrm{~cm}$. Aquarium dicuci hingga bersih dengan menggunakan diterjen dan dibilas dengan air, kemudian dikeringkan selama 4 jam di bawah sinar matahari. Selanjutnya aquarium diisi air sebanyak 15 liter, kemudian dipasangkan peralatan aerasi sebagai penyuplai oksigen untuk menjaga kekurangan oksigen bagi ikan yang dipelihara kelengsungan hidup ikan kerapu macan.

\section{Persiapan Ikan}

Ikan yang digunakan dalam penelitian ini adalah ikan kerapu yang ukuran benih dengan berat/ bobot 8-10 gram sebanyak 5 ekor/ wadah. Ikan yang digunakan adalah ikan yang sehat dan tidak memiliki gejala terserang bakteri atau penyakit, seperti terdapat borok pada kulit, bintik hitam/ putih dan busuk pada sirip. Ikan diaklimatisasi terlebih dahulu selama 7 hari untuk menurunkan tingkat stress, selama tahapan aklimatisasi ikan diberikan pakan dengan bobot pakan yang diberikan adalah $5 \%$ dari biomas ikan. Pemberian pakan pada ikan 
dilakukan pada pagi dan sore hari.

\section{Persiapan Ekstrak Buah Mahkota Dewa}

Buah mahkota dewa yang di persiapkan dalam penelitian ini adalah buah yang masih segar dengan berat 5 dan 10 gram dipotong-potong sampai berukuran kecil-kecil dan dimasukan dalam air sebanyak $100 \mathrm{ml}$ untuk direbus. Perebusan buah mahkota dewa dilakukan sampai sisa air $50 \mathrm{ml}$ (Wahjuningrum et al., 2007). Larutan baku hasil rebusan tersebut kemudian diencerkan dengan menggunakan aquades.

\section{Perendaman Ikan}

Ikan yang telah diaklimatisasi selama 7 hari, direndam dalam air yang telah diberikan larutan buah mahkota dewa. Perbandingan air perendaman dengan larutan buah mahkota dewa adalah $10 \mathrm{ml} /$ liter. Volume air perendaman yang digunakan adalah 6 liter, sedangkan larutan buah mahkota dewa yang digunakan adalah $60 \mathrm{ml}$. Perendaman dilakukan selama \pm 20 menit dan dilakukan 2 kali dengan jarak satu hari setelah perendaman pertama akan dilakukan perendaman ke dua (Abiddinda 2013). Setelah perendaman dilakukan pemeliharaan selama 10 hari dengan tetap melakukan pemberian pakan. Pakan yang di berikan pada ikan kerapu macan pada saat pemeliharaan adalah pakan pelet, pemberian pakan dilakukan 2 kali sehari yaitu pagi dan sore hari. Pemberian pakan dilakukan secara adlibitum.

\section{Prevalensi Bakteri}

Prevalensi merupakan tingkat serangan bakteri terhadap ikan kerapu pada saat uji tantang yang dihitung dengan menggunakan rumus dari Fidyandini et al., 2012, yaitu :

Prevalensi $=\frac{\text { Jumlah } i \text { kan yang terserang bakteri }}{\text { Jumlah ikan yang diperiksa }} \times 100 \%$

\section{Pertumbuhan}

Pertumbuhan ikan kerapu selama pemeliharaan juga menjadi parameter pengamatan selama penelitian. Pengukuran pertumbuhan dapat dihitung dengan menggunakan rumus dari Effendie, 2004, yaitu :

$$
\mathrm{Wm}=\mathrm{Wt}-\mathrm{Wo}_{\mathrm{o}}
$$

Dimana: Wm: Penambahan Berat (Gram), Wt: Berat Akhir (Gram), Wo : Berat Awal (Gram)

\section{Kelangsungan hidup}

Tingkat kelangsungan hidup dihitung pada akhir penelitian untuk melihat efektifitas ekstrak buah mahkota dewa dalam menghambat serangan Aeromonas hydrophilla pada ikan kerapu. Tingkat kelangsungan hidup dapat dihitung dengan menggunakan rumus dari Effendie (2004), yaitu :

$$
\mathrm{SR}=(\mathrm{Nt} / \mathrm{No}) \times 100
$$

Keterangan : SR = Tingkat kelangsungan hidup (\%), $\mathrm{Nt}=$ Jumlah ikan yang hidup pada tahap akhir (ekor) No = Jumlah ikan yang hidup pada tahap awal (ekor)

\section{Analisa Data}

Data yang dikumpulkan diolah dengan analisa varian (Anova), jika terdapat perbedaan yang berbeda nyata dari tiap-tiap perlakuan yang diberikan, maka akan dilakukan uji lanjut dengan mengunakan Uji Beda Nyata Tujur (BNT).

\section{HASIL}

\section{Prevalensi}

Prevalensi merupakan tingkat serangan bakteri Aeromonas hydrophilla terhadap ikan kerapu yang menyebabkan timbulnya gejala klinis pada saat uji tantang. Adapun tingkat prevalensi Aeromonas hydrophilla pada ikan kerapu dapat dilihat pada Tabel 1. berikut ini :

Tabel 1. Tingkat Prevalensi Aeromonas hydrophilla

\begin{tabular}{|c|c|c|c|}
\hline $\begin{array}{l}\text { Perlakua } \\
\mathrm{n}\end{array}$ & $\begin{array}{l}\text { Jumlah Ikan } \\
\text { Terinfeksi } \\
\text { (ekor) }\end{array}$ & $\begin{array}{l}\text { Jumlah } \\
\text { Ikan Uji } \\
\text { (ekor) }\end{array}$ & $\begin{array}{l}\text { Prevale } \\
\text { nsi (\%) }\end{array}$ \\
\hline A & 13 & 15 & 86,66 \\
\hline B & 12 & 15 & 80 \\
\hline $\mathrm{C}$ & 15 & 15 & 100 \\
\hline $\begin{array}{ll}\text { Ket } & : \mathrm{A} \\
& : \mathrm{B} \\
& : \mathrm{C}\end{array}$ & $\begin{array}{l}: 1 \mathrm{ml} \text { ekstrak buah } \\
: 2 \mathrm{ml} \text { ekstrak buah } \\
: 0 \mathrm{ml} \text { ekstrak buah }\end{array}$ & $\begin{array}{l}\text { ahkota dewa/ } 9 \\
\text { ahkota dewa/ } 8 \\
\text { ahkota dewa }\end{array}$ & $\begin{array}{l}l \text { aquades } \\
l \text { aquades }\end{array}$ \\
\hline
\end{tabular}
pada Ikan Kerapu

Berdasarkan Tabel 1 di atas diketahui perbedaan tingkat prevalensi Aeromonas hydrophilla pada ikan kerapu pada saat uji tantang yang tertinggi terdapat pada perlakuan C yaitu dengan tingkat prevalensi $100 \%$ dan tingkat prevalensi yang terendah terdapat pada perlakuan B yaitu $80 \%$. Hal ini diduga karena pada perlakuan $\mathrm{C}$ tidak diberikan perendaman dengan menggnakan ekstrak buah mahkota 
dewa, jadi pada saat uji tantang dengan menggunakan bakteri Aeromonas hydrophilla, ikan dapat diserang dengan leluasa tanpa adanya pertahanan. Ikan kerapu pada perlakuan $\mathrm{C}$ mati semua setelah 5 hari pasca uji tantang menggunakan bakteri Aeromonas hydrophilla.

Sedangkan pada perlakuan B yang telah diberikan perendaman dengan menggunakan ekstrak buah mahkota dewa, ikan kerapu telah memiliki senyawa antimikroba dan antibakteri, sehingga ikan dapat menghambat serangan bakteri Aeromonas hydrophilla pada saat uji tantang.

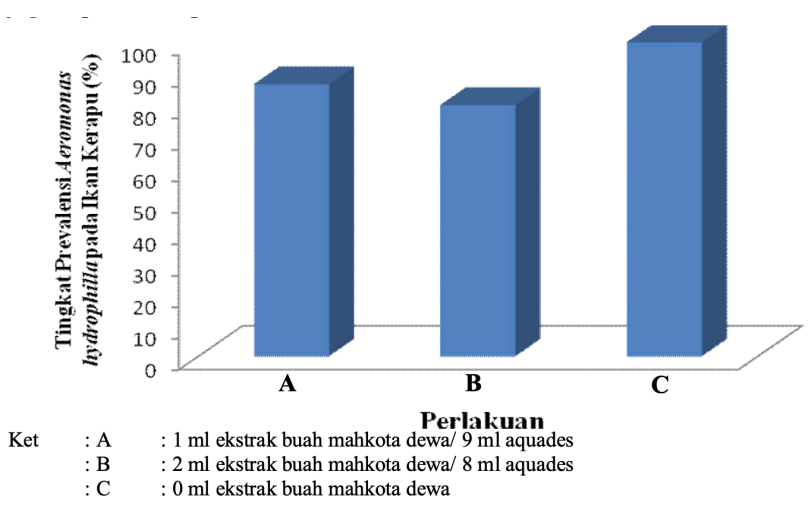

Gambar 1. Tingkat Prevalensi Bakteri A. hydrophilla pada Ikan Kerapu

\section{Pertambahan Bobot Tubuh}

Ikan kerapu yang digunakan dalam penelitian ditimbang berat tubuhnya. Berat tubuh ikan kerapu yang digunakan seragam dengan berat/ekor 22 - 23 gram. Alasan memilih ukuran yang seragam adalah supaya tidak terjadi kanibalisme antara benih ikan yang digunakan dan tidak menyebabkan persaingan selama pemeliharaan. Jumlah ikan yang digunakan dalam tiap-tiap wadah adalah 5 ekor. Adapun pertambahan bobot tubuh rata-rata selama penelitian disajikan pada Tabel 2 di bawah ini :

Tabel 2. Rata-rata Berat dan Pertambahan Bobot Tubuh Ikan Kerapu selama Penelitian

\begin{tabular}{|c|c|c|c|}
\hline $\begin{array}{l}\text { Perlakua } \\
\mathrm{n}\end{array}$ & $\begin{array}{l}\text { Bobot } \\
\text { Awal } \\
\text { (Gram) }\end{array}$ & $\begin{array}{l}\text { Bobot } \\
\text { Akhir } \\
\text { (Gram) }\end{array}$ & $\begin{array}{l}\text { Pertambahan } \\
\text { Bobot (Gram) }\end{array}$ \\
\hline A & 22,91 & 34,06 & 11,15 \\
\hline B & 22,80 & 36,43 & 13.63 \\
\hline $\mathrm{C}$ & 22,82 & 28,57 & 5,75 \\
\hline $\begin{array}{l}: \mathrm{A} \\
: \mathrm{B} \\
: \mathrm{C}\end{array}$ & $\begin{array}{l}: 1 \mathrm{ml} \mathrm{ek} \\
: 2 \mathrm{ml} \mathrm{ek} \\
: 0 \mathrm{ml} \mathrm{ek}\end{array}$ & uah mah & $\begin{array}{l}\text { ewa/ } 9 \mathrm{ml} \text { aquades } \\
\text { ewa/ } 8 \mathrm{ml} \text { aquades } \\
\text { ewa }\end{array}$ \\
\hline
\end{tabular}

Berdasarkan Tabel 2 di atas dapat dilihat bahwa hasil penelitian menunjukan, pertambahan bobot tubuh ikan kerapu paling tinggi terdapat pada perlakuan B yaitu dengan pertambahan bobot tubuh 13,63 gram waktu pemeliharaan selama 30 hari. Pertambahan bobot tubuh tertinggi pada perlakuan B diduga karena pemberian ekstrak buah mahkota dewa dengan dosis $2 \mathrm{ml}$ efektif mencegah serangan bakteri Aeromonas hydrophilla dan dapat meningkatkan efisisensi pakan, karena nutrisi yang diperoleh dari pakan tidak dimanfaatkan ikan untuk menjaga kesehatan tubuh, tetapi hanya dimanfaatkan untuk pertumbuhan.

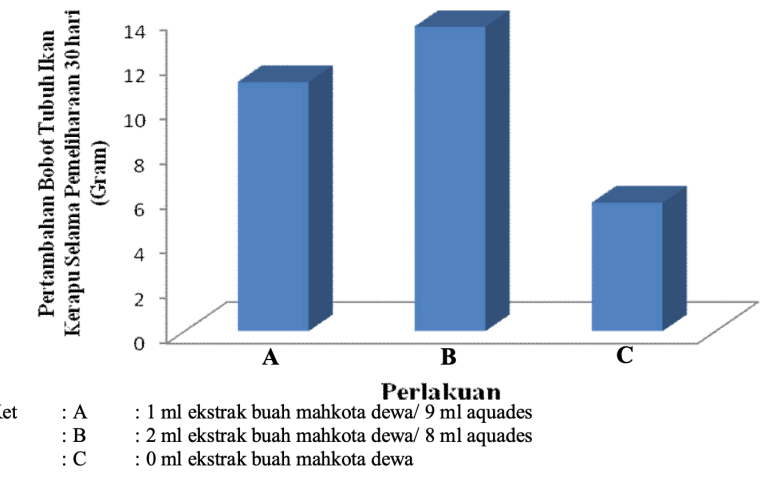

Gambar 2. Grafik Penambahan Berat Tubuh Ikan Kerapu

Pada saat pemeliharaan, ikan kerapu yang telah diberikan perendaman dengan menggunakan ekstrak buah mehkota dewa, memiliki respon terhadap pakan, meskipun respon yang ditunjukkan tidak begitu baik, tetapi ikan kerapu yang tidak diberikan perendaman dengan menggunakan ekstrak buah mahkota dewa, pada saat pemeliharaan pasca uji tantang, menunjukkan gejala tidak merespon pakan yang diberikan. Oleh karena itu pertambahan bobot tubuh ikan kerapu menjadi rendah.

\section{Pertambahan Panjang}

Petambahan panjang ikan kerapu juga merupakan indikator pertumbuhan dari ikan kerapu yang dipelihara (Fitriah, 2004). Untuk pertambahan panjang ikan kerapu pada saat pemeliharaan selama 30 hari disajikan pada Tabel 3. Berdasarkan Tabel 3 dapat dilihat bahwa pertumbuhan ikan kerapu berdasarkan panjang tubuh yang paling tinggi terdapat pada perlakuan B dengan rata-rata pertambahan panjang tubuh adalah $2,3 \mathrm{~cm}$ dan pertambahan panjang yang terendah terdapat pada perlakuan $\mathrm{C}$ dengan rata-rata pertambahan panjang 
adalah $1,3 \mathrm{~cm}$ pada saat pemeliharaan selama 30 hari. Hasil uji Anava pertambahan panjang ikan kerapu menunjukan hasil nilai Fhitung > Ftabel 0,01 . Hasil perhitungan uji BNT menunjukan bahwa yang memberikan pengaruh yang berbeda pada pertambahan panjang tubuh ikan terdapat pada perlakuan B.

Tabel 3. Rata-rata Berat dan Pertambahan Panjang Tubuh Ikan Kerapu selama Penelitian

\begin{tabular}{|c|c|c|c|}
\hline $\begin{array}{l}\text { Perlaku } \\
\text { an }\end{array}$ & $\begin{array}{l}\text { Panjang } \\
\text { Awal } \\
(\mathrm{cm})\end{array}$ & $\begin{array}{l}\text { Panjang } \\
\text { Akhir (cm) }\end{array}$ & $\begin{array}{l}\text { Pertambahan } \\
\text { Panjang }(\mathrm{cm})\end{array}$ \\
\hline $\mathrm{A}$ & 8,8 & 10,5 & 1,7 \\
\hline B & 9,5 & 11,8 & 2,3 \\
\hline $\mathrm{C}$ & 9,2 & 10,5 & 1,3 \\
\hline $\begin{array}{ll}\text { et } & : \mathrm{A} \\
& : \mathrm{B} \\
& : \mathrm{C}\end{array}$ & $\begin{array}{l}: 1 \mathrm{ml} \text { ekstı } \\
: 2 \mathrm{ml} \text { ekstı } \\
: 0 \mathrm{ml} \text { ekstı }\end{array}$ & $\begin{array}{l}\text { buah mahko } \\
\text { buah mahko } \\
\text { buah mahko }\end{array}$ & $\begin{array}{l}\text { lewa/ } 9 \mathrm{ml} \text { aquades } \\
\text { lewa/ } 8 \mathrm{ml} \text { aquades } \\
\text { lewa }\end{array}$ \\
\hline
\end{tabular}

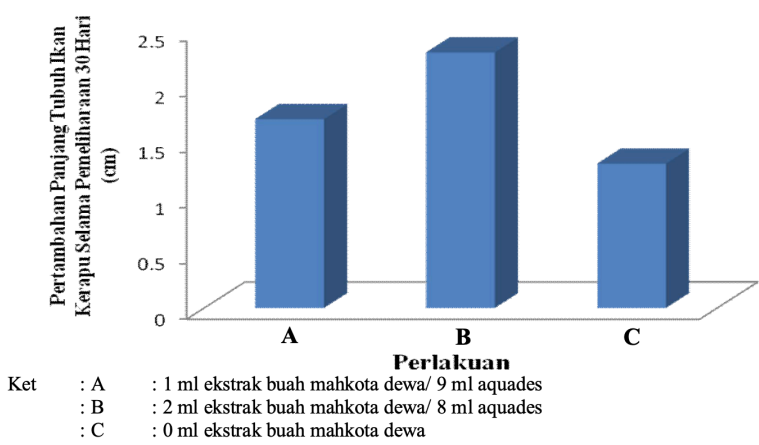

Gambar 3. Grafik Pertambahan Panjang Ikan kerapu

\section{Kelangsungan Hidup}

Tingkat kelangsungan hidup dari ikan kerapu selama pemeliharaan pasca uji tantang dengan menggunakan Aeromonas hydrophilla yang diberikan perlakuan perendaman dengan menggunakan ekstrak buah mahkota dewa dengan dosis yang berbeda dan tanpa perendaman dengan ekstrak buah mahkota dewa dapat dilihat pada Tabel 4 di bawah ini :

Tabel 4. Tingkat Kelangsungan Hidup Ikan Kerapu

\begin{tabular}{|c|c|c|c|}
\hline $\begin{array}{l}\text { Perlakua } \\
\mathrm{n}\end{array}$ & $\begin{array}{l}\text { Jumlah } \\
\text { Awal } \\
\text { (ekor) }\end{array}$ & $\begin{array}{l}\text { Jumlah } \\
\text { Akhir } \\
\text { (ekor) }\end{array}$ & $\begin{array}{l}\text { Kelangsun } \\
\text { gan Hidup } \\
(\%)\end{array}$ \\
\hline A & 15 & 2 & 13,33 \\
\hline B & 15 & 3 & 20 \\
\hline $\mathrm{C}$ & 15 & 0 & 0 \\
\hline $\begin{array}{l}: \mathrm{A} \\
: \mathrm{B} \\
: \mathrm{C}\end{array}$ & $\begin{array}{l}: 1 \mathrm{ml} \text { ekst } \\
: 2 \mathrm{ml} \text { ekst } \\
: 0 \mathrm{ml} \text { ekst }\end{array}$ & h mahkota & $\begin{array}{l}9 \mathrm{ml} \mathrm{aq} \\
8 \mathrm{ml} \text { aq }\end{array}$ \\
\hline
\end{tabular}

Berdasarkan Tabel 4.8 di atas dapat dilihat tingkat kelangsungan hidup ikan kerapu tertinggi terdapat pada perlakuan B yaitu $20 \%$, dan yang terendah terdapat pada perlakuan $\mathrm{C}$ yaitu $0 \%$.

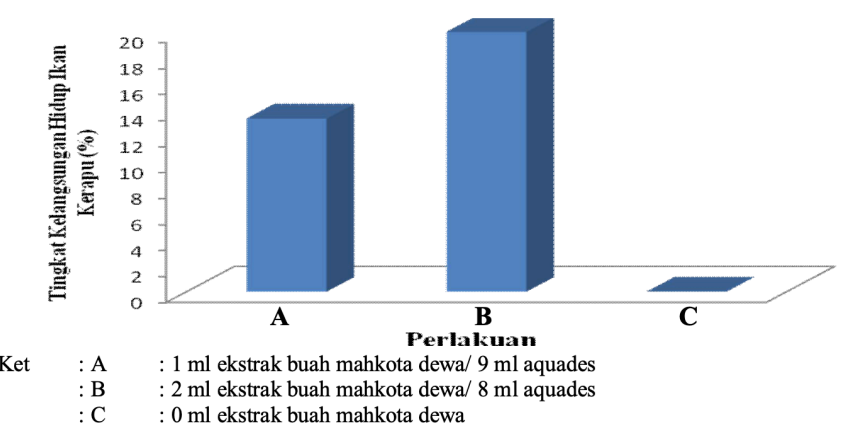

Gambar 4. Grafik Tingkat Kelangsungan Hidup Ikan Kerapu

Ikan kerapu yang tidak diberikan perendaman dengan ekstrak buah mahkota dewa, tingkat kelangsungan hidupnya paling rendah yaitu $0 \%$. Hal ini disebabkan pada saat ikan diuji tantang, ikan kerapu tidak memiliki daya tahan tubuh yang dapat menghambat serangan bakteri $A$ hydrophilla yang berupa senyawa antimikroba, dan antibakteri. Pada uji Anova tingkat kelangsungan hidup ikan kerau tidak menunjukan hasil yang berbeda nyata, yaitu nilai Fhitung $<$ Ftabel 0,05.

\section{PEMBAHASAN}

Ekstrak buah mahkota dewa memiliki senyawa kimia yang bersifat sebagai anibakteri dan antioksidan pada tubuh ikan. Senyawa kimia antibakteri dan antioksidan tersebutlah yang diduga menjadi penghambat serangan bakteri Aeromonas hydrophilla pada ikan kerapu pada saat uji tantang dan sedikit aktif setelah uji tantang (Widyastuti et al., 2006). Buah mahkota dewa mengandung senyawa antibakteri, antimikroba dan antioksidan yang berupa senyawa folifenol, alkaloid dan flafonoid yang dapat menjadi penghambat terhadap serangan bakeri pada ikan yang dibudidayakan (Abiddinda 2013). Sedangkan untuk gejala klinis yang terburuk terdapat pada perlakuan A dan C dengan gejala klinis yang ditunjukkan adalah warna tubuh pucat. Untuk gejala klinis dari tingkah laku, ikan kerapu menunjukkan pergerakan yang lamban, sering berdiam diri di dasar dan sudut akuarium, Ikan sering berenang kepermukaan dan dasar perairan.

Ikan kerapu tidak memilki respon terhadap pakan yang diberikan dan banyak pakan yang 
tersisa dan mengendap di dasar akuarium. Kordi (2004), menjelaskan ciri ikan yang terserang Aeromonas hydrophilla ditandai dengan adanya luka atau pembengkakan pada bagian luar tubuh, nafsu makan menjadi turun, produksi lendir berlebihan dan feses ikan lengket pada bagian anus. Menurut Kordi dan Ghufran (2004), tanda-tanda sekunder serangan bakteri Aeromonas hydrophila terlihat dengan tumbuhnya jamur berwarna putih pada bagian ujung sirip ikan dan pada bagian tubuh yang mengalami luka memar, ikan berenang tidak beraturan dan lebih banyak berdiam diri dan menyendiri.

Pada perlakuan B yang telah diberikan perendaman dengan menggunakan ekstrak buah mahkota dewa, ikan kerapu telah memiliki senyawa antimikroba dan antibakteri, sehingga ikan dapat menghambat serangan bakteri Aeromonas hydrophilla pada saat uji tantang. Buah mahkota dewa memilki senyawa antibakteri dan antimikroba seperti yang telah diterangkan oleh Wijoyo (2012). Buah mahkota dewa mengandung senyawa antibakteri yang dapat mencegah serangan bakteri pada hewan dan biota perairan (Widowati, 2005).

Buah mahkota dewa mengandung senyawa antibakteri yang mencegah serangan bakteri pada ikan (Yanto, 2013). Sedangkan pertambahan bobot paling rendah terdapat pada perlakuan $\mathrm{C}$ yaitu dengan pertamabahan bobot 5,75 gram. Hal ini diduga karena ikan kerapu yang telah diberikan perlakukan perendaman dengan menggunakan ekstrak buah mahkota dewa selama 15 menit dapat menjaga daya tahan tubuh sedikit lebih baik dibandingkan dengan ikan kerapu yang tanpa perendaman dengan menggukana ekstrak buah mahkota dewa.

Ikan kerapu yang diberikan perlakuan perendaman dengan ekstrak buah mahkota dewa dosis $2 \mathrm{ml}$ memiliki tingkat kelangsungan hidup yang lebih tinggi, hal ini diduga karena daya antibakteri pada buah mahkota dewa dapat menghambat $A$. hydrophilla yang di uji tantang kepada ikan kerapu. Ekstrak buah mahkota dewa yang diberikan pada ikan kerapu efektif meningkatkan tingkat kelangsungan hidup ikan kerapu, karena buah mahkota dewa mengandung senyawa antibakteri (Yanto, 2013).

\section{KESIMPULAN}

Ekstrak buah mahkota dewa dengan dosis $1 \mathrm{ml}$ dan 2 ml tidak dapat mencegah serangan bakteri Aeromonas hydrophilla terhadap ikan kerapu dengan tingkat prevalensi berkisar $80-86,6 \%$. Namun pertumbuhan panjang dan bobot ikan yang diberi perlakuan dosis ekstrak buah mahkota dewa $1 \mathrm{ml}$ dan $2 \mathrm{ml}$ menunjukkan efek positif.

\section{DAFTAR PUSTAKA}

Abiddinda, A. (2013). Efek Daya Antibakteri Ekstrak Buah Mahkota Dewa (Phaleria macrocarpa (Scheff.) Boerl) Terhadap Pertumbuhan Bakteri Streptococcus mitis (Kajian In Vitro) (Doctoral dissertation, [Yogyakarta]: Universitas Gadjah Mada).

Effendie, I. 2004. Pengantar Akuakultur. PT. Penebar Swadaya. Jakarta.

Fidyandini, H. P., \& Subekti, S. (2012). Identifikasi dan Prevalensi Ektoparasit pada Ikan Bandeng (Chanos chanos) yang Dipelihara Di Karamba Jaring Apung Upbl Situbondo Dan Di Tambak Desa Bangunrejo Kecamatan Jabon Sidoarjo Identification And Prevalence Of Ectoparasites On. Journal of Marine and Coastal Science, 1(2), 91-112.

Ghufran, M., \& Kordi, K. (2004). Penanggulangan hama dan penyakit ikan. PT. Sadi Mahasatya, Jakarta.

Wahjuningrum, D., Angka, S. L., Lesmanawati, W., \& Yuhana, M. (2007). Prospect use of Phaleria macrocarpa to prevent motile aeromonad septicaemia disease in Patin Catfish Pangasianodon hypophthalmus. Jurnal Akuakultur Indonesia, 6(1), 109-117.

Widowati, L. (2005). Kajian hasil penelitian Mahkota dewa. Jurnal bahan alam Indonesia, 4(1), 223227.

Widyastuti, N., Widiyani, T., \& Listyawati, S. (2006). Efek Teratogenik Ekstrak Buah Mahkota Dewa (Phaleria macrocarpa (Scheff.) Boerl.) pada Tikus Putih (Rattus norvegicus L.) Galur Winstar. Bioteknologi, 3(2), 56-62.

Wijoyo, P. M. (2012). Rahasia Sukses Mencegah Kematian Koi. Pustaka Agro Indonesia, Jakarta Selatan.

Yanto, H. (2013). Potensi Antibakteri Mahkota Dewa Untuk Pencegahan Infeksi Bakteri Aeromonas Hidrophyla Pada Ikan Lele Dumbo (Clarias sp). Jurnal Ruaya: Jurnal Penelitian dan Kajian Ilmu Perikanan dan Kelautan, 2(2). 